\title{
Mid-level synoptic analysis of flood-generating systems in South-west of Iran (case study: Dalaki watershed river basin)
}

\author{
A. A. Sabziparvar ${ }^{1}$, A. Parandeh ${ }^{2}$, H. Lashkari ${ }^{3}$, and H. Yazdanpanah ${ }^{4}$ \\ ${ }^{1}$ Faculty of Agriculture, Bu-Ali Sina University, Hamedan, 65174, I. R. Iran \\ ${ }^{2}$ Meteorological Research Centre, Esfahan, I. R. Iran \\ ${ }^{3}$ Department of Geography, University of Shahid Beheshti, Tehran, I. R. Iran \\ ${ }^{4}$ Department of Geography, University of Esfahan, Esfahan, I. R. Iran
}

Received: 29 August 2008 - Revised: 9 March 2010 - Accepted: 12 July 2010 - Published: 16 November 2010

\begin{abstract}
Flood is known as one of the most distractive natural disaster worldwide. Therefore, its prediction is of great importance from the socio-economical point of view. Despite the great improvement in computational techniques and numerical weather prediction approaches, so far, in Iran, an acceptable flood prediction method has not yet been introduced. The main aim of this study is to recognize and classify the patterns of synoptic systems leading to torrential rainfalls in a watershed basin located in south-west of Iran. In this research, 20 major floods characterized by high rainfall intensities and severe damage were selected. The pattern, extension, and the direction of movement of the selected synoptic maps from surface to $500 \mathrm{hPa}$ pressure levels were identified. Furthermore, the position of cyclones, anti-cyclones and mid-level trough lines were carefully tracked and classified into different groups. The results show that the major severe floods occurring in Dalaki watershed river basin are mainly influenced by strengthening of the center of Sudan heat low (SHL) and the coincidence moisture feeding by the Indian Ocean and Mediterranean Sea. It was found that simultaneous merging of the SHL system and Mediterranean frontal system would intensify the flood intensities over the basin. The mean positions of high pressures, low pressures, the Red Sea trough lines and $1015 \mathrm{hPa}$ isobars of the major floods are also discussed.
\end{abstract}

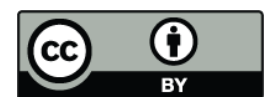

Correspondence to: A. A. Sabziparvar (swsabzi@basu.ac.ir)

\section{Introduction}

Forecasting rainfall depths and flood risk assessment are important input components of many hydro-meteorological models, especially for flash-flood forecasting models (Hall et al., 2005; Taramasso et al., 2005). Inundation is one of the natural disasters, which causes many damages worldwide. Therefore, its prediction is of great concern for preventing economical and human losses, in particular, in vulnerable areas. Iran is located in a semi-arid region where is mainly governed by Subtropical High Pressure (SHP) systems (Sabziparvar, 2008). Due to the presence of the SHP systems, according to Köppen climate classification, Iran is known as semi-arid and arid region (Sabziparvar and Ghafouri, 2008). The mean annual rainfall of Iran is about $242 \mathrm{~mm}$ (Dinpashoh et al., 2004). Unfortunately, due to high variability of precipitation, the spatial and temporal distribution.of this little rainfall are not uniform throughout the country. Based on the improper topography, soil conditions and plant coverage, most of the heavy rainfalls could not penetrate into the ground. This leads to sudden run-off flows in the affected areas. The official reports indicate that many people loss their lives, animals, and agricultural crops as a result of distractive floods, especially in south-west of Iran. In this regard, the fountainhead of Dalaki watershed basin causes many damaging floods.

Many researchers classified synoptic patterns prior and after flood events under different climate conditions. Synoptic conditions leading to cyclogenesis and frequent floods over eastern South America were predicted by Seluchi (1995). Turner et al. (1997) studied the variability of precipitation over coastal region of the Antarctic Peninsula from synoptic observation. They concluded that the heavy precipitations are dependent on the synoptic pattern, but independent

Published by Copernicus Publications on behalf of the European Geosciences Union. 
of temperature over the region. Also, the similar evaluation was performed by Konrad (1997) using 312 case studies over south-east America.

Flood-causing rainstorms have been an interesting task in some countries. Kahana et al. (2004) used atmospheric predictors for prediction of major floods over Negev desert in Israel. The frequency of occurrence of the East Mediterranean synoptic system, bearing rainfall, was compared for a period of 28 years by Osetinsky and Alpert (2006). Analysis of an extreme hydro-meteorological case that generated severe rainstorm over Israel was also investigated by Morin el al. (2007). Březková et al. (2007) reviewed the predictability of flood events from the meteorological and hydrological points of views in the climate condition of the Czech Republic. In another case, Dayan et al. (2001) analyzed the synoptic and mesoscale convection leading to intense thunderstorm, extreme rain and floods over the Middle-East. They showed that the presence of the Red Sea trough, mid-level moisture transport from northern Africa supported by upperlevel divergence, are the main causes of torrential floods over the Middle-East. The important role of Mediterranean cyclonic activity and the Red Sea troughs in transporting heavy rainfall to the countries located in the east Mediterranean was also addressed by Ziv et al. (2005).

Although the impacts of topography, morphology, soil moisture condition, plant coverage, flood management and river discharge on likelihood of flood events are not in the scope of this study, the above subjects have been investigated by many workers (e.g. Calena et al., 1992; Steromberg et al., 1993; Cozari et al., 1994; Chai et al., 1995; Alexander et al., 1998).

During the last two decades, a few studies have addressed the synoptic analysis of flood-generating systems in Iran. Sabziparvar (1991) investigated the major causes of torrential rainfalls at south-west of Iran. He found that the presence of subtropical jet streams can provide suitable conditions for heavy rainfalls in southwest of Iran. The same study was conducted by Bagheri (1993) in the North of the country. He showed that the flooding synoptic systems in the North, are mainly influenced by the North Atlantic anticyclones supported by central pressure of $1025-1035 \mathrm{hPa}$, spreading over the Caspian sea. Unfortunately, the majority of the mentioned studies have used a short period of time supported by a few synoptic factors for their analysis.

The main objectives of this work are the study of position, transition, direction, and dynamical strength of different large scale synoptic systems (e.g. Sudan heat lows, Subtropical anticyclones, Mediterranean frontal systems) at various low-level and mid-level charts over the flood vulnerable basin of Dalaki river basin (South-west of Iran).

For the sake of prediction purposes, the synoptic patterns are discussed and classified into different groups, from $48 \mathrm{~h}$ prior to the flood events. The results of this research can provide useful information for policy makers in issuing ontime flood warning for the similar regions.

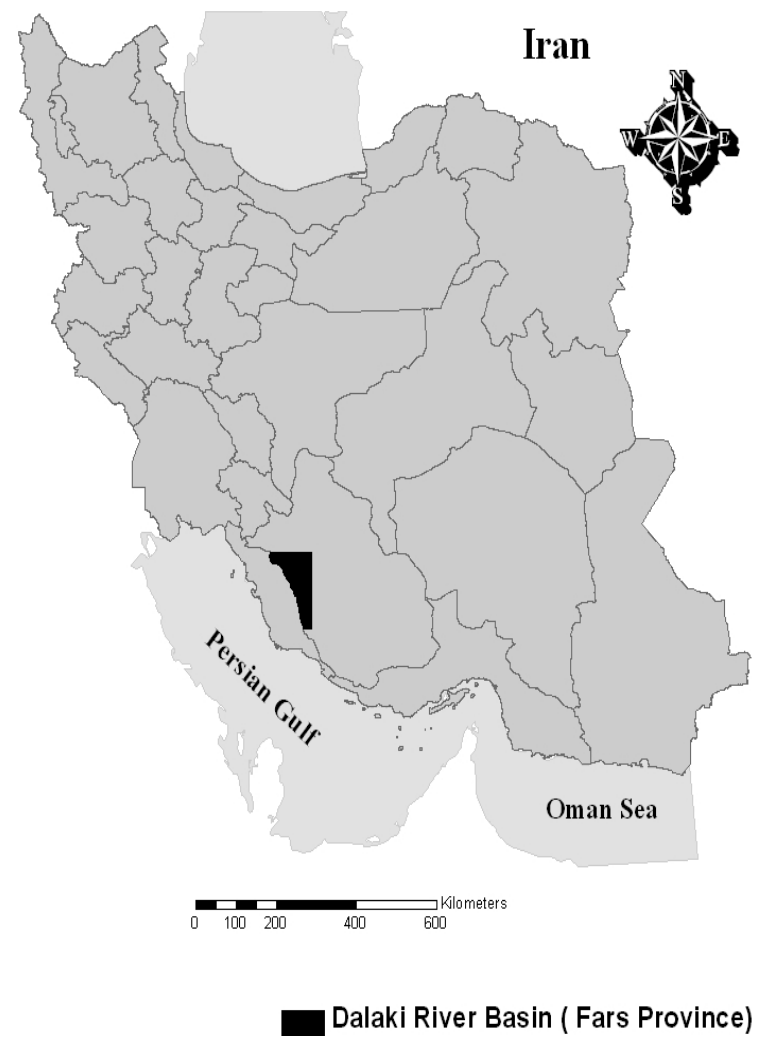

Fig. 1. The geographical location of Dalaki watershed basin.

\section{Methodology}

\subsection{Site location}

The Dalaki watershed basin is located at the south-west of Fars province. This basin is geographically located between $28^{\circ} 14^{\prime}$ to $29^{\circ} 41^{\prime} \mathrm{N}$ and $51^{\circ} 05^{\prime}$ to $52^{\circ} 21^{\prime} \mathrm{E}$ (Fig. 1). The fountainhead of Dalaki watershed basin is more than $1300 \mathrm{~m}$ a.s.l., which covers an area of about $6000 \mathrm{~km}^{2}$. The long-term historical records indicate that this basin is vulnerable to the flood occurrence with periodically significant socio-economical losses (Jamab, 1990). The hydrological discharge of this basin is considered as a major fountainhead of the Persian Gulf basin.

\subsection{Synoptic data}

To study the rain-bearing systems, during the period of study, the data were obtained from the Iranian Meteorological Office (IRIMO) data center and successive synoptic maps at surface level (AAXX), $850 \mathrm{hPa}, 700 \mathrm{hPa}$, and $500 \mathrm{hPa}$ levels were plotted. The exact dates of flood events in Dalaki were taken from Iranian Ministry of Interior, Office of Natural Disasters, and their coincidence were checked with the local newspapers accordingly. 


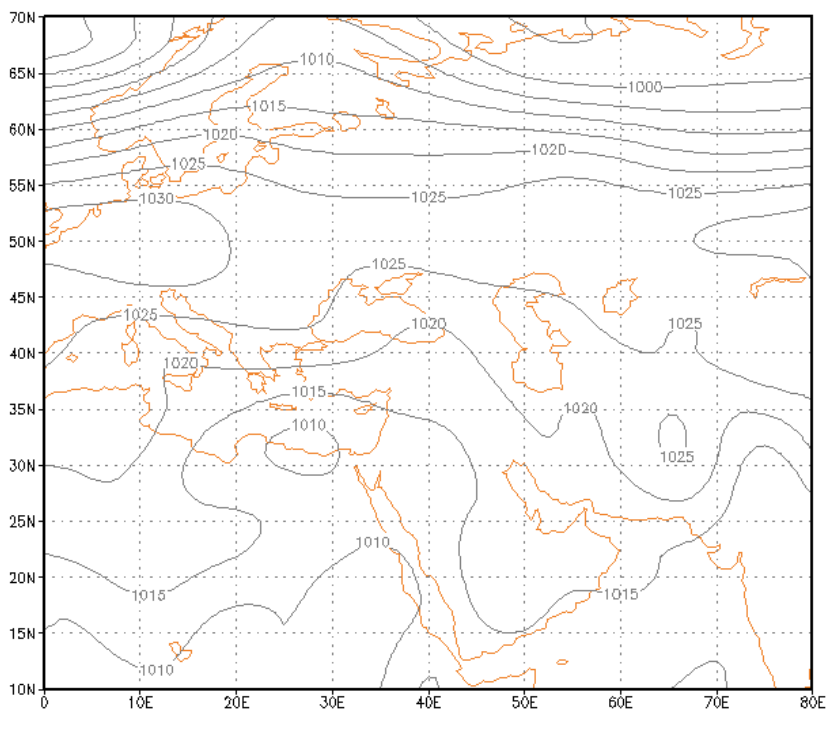

GrRAS: COLA/GES

2009-07-27-68:12

Fig. 2. The pattern of the surface isobars (AAXX) $48 \mathrm{~h}$ before the rainfall (type I: 28 November 1986).

\subsection{Method of research}

In this study the synoptic maps of the surface (AAXX), $850 \mathrm{hPa}, 700 \mathrm{hPa}$, and $500 \mathrm{hPa}$ levels were analyzed. However, for the sake of brevity, the results are mainly presented and discussed at two levels; surface and $500 \mathrm{hPa}$. In this work, it is assumed that the most deterministic synoptic factors, which are associated with the torrential heavy rainfall in the study region are: Mediterranean cyclones, Sudan heat low, Siberian anticyclones (high pressures) and the Azores high pressure systems.

From the information existed on the synoptic maps, the factors affecting rainfall depths such as: position and direction of movement of centers of cyclones and anticyclones, pattern of isobars, moisture content of the systems (dew point temperature) and the position of low-level and midlevel trough, were successively recorded from $48 \mathrm{~h}$ prior to the occurrence of heavy rainfall in the region.

\section{Results and discussion}

The characteristics and spatial patterns of all synoptic maps were carefully studied in details from $48 \mathrm{~h}$ prior to rainfalls. Although in many cases, the synoptic patterns of the flood generating systems were similar, for the simplicity and easy understanding, the patterns of the selected rain-bearing systems were classified into four different groups:

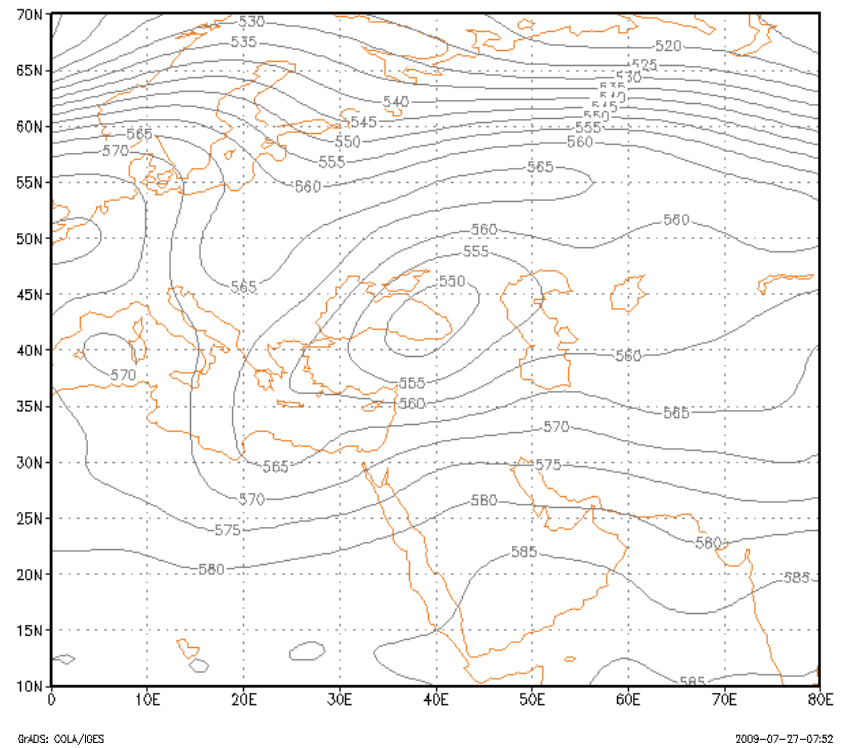

Fig. 3. The pattern of the geopotential heights and the position of trough line at $500 \mathrm{hPa}$ level $48 \mathrm{~h}$ before the rainfall (type I: 28 November 1986).

\subsection{Type I}

\subsubsection{Synoptic characteristics before the rainfall}

\section{Surface level}

In type I, the synoptic surface maps $48 \mathrm{~h}$ before the rainfall show that the Siberian high pressure (SHP) isobars are moved southward from their normal positions. Therefore, the SHP isobars are extended over most part of Iran and merged with the isobars of high pressure center located at eastern regions of the Arabian Peninsula. This condition will feed moisture from Indian ocean and Oman sea into the Sudan heat low (SHL) which is positioned over the Red Sea with the central pressure of $1010 \mathrm{hPa}$ (Fig. 2).

\section{$500 \mathrm{hPa}$ level}

The geopotential maps at $500 \mathrm{hPa}$ before the rainfall are characterized with a deep trough over the eastern Mediterranean and north Africa. This situation will provide cold advection from higher latitudes, which dynamically intensify low pressure (LP) system at the surface (Fig. 3).

\subsubsection{Synoptic characteristics after the rainfall}

\section{Surface level}

The synoptic pattern of surface charts after starting the rainfall (Fig. 4) has been changed, in comparison with the previous conditions ( $48 \mathrm{~h}$ ago). As a result, the Siberian high pressure (HP) isobars have moved back northward, allowing low pressure rain-bearing system to approach to the study 


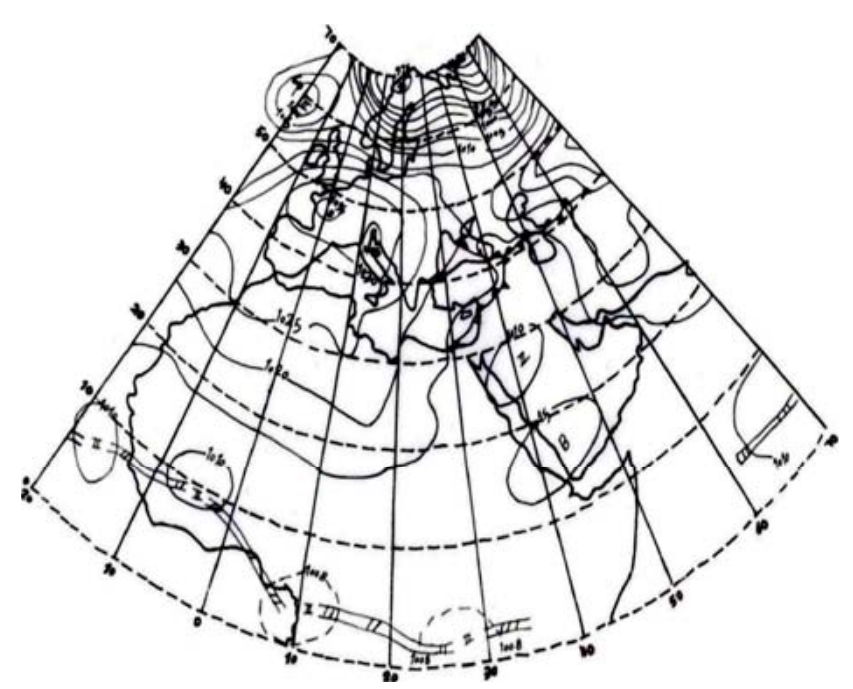

Fig. 4. The pattern of the surface isobars $(A A X X)$ after the rainfall (type I: 1 December 1986).

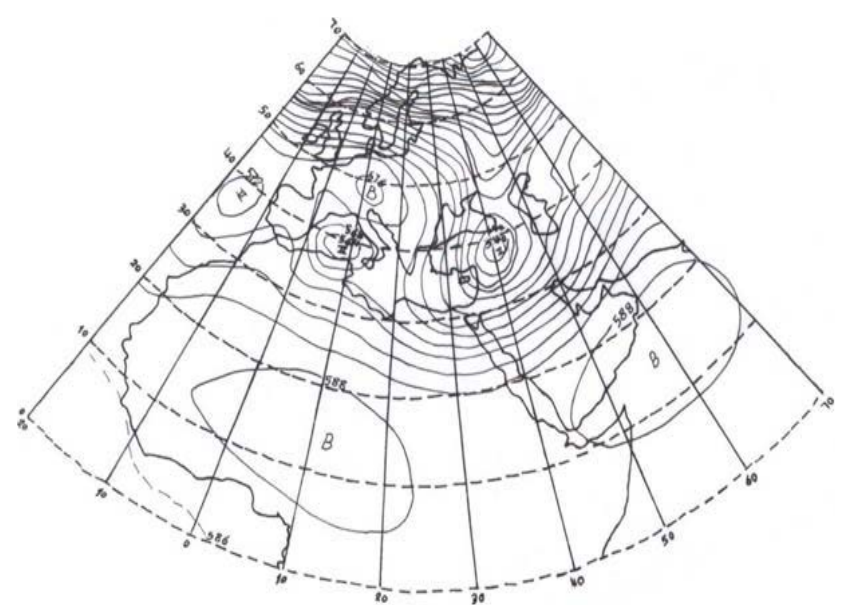

Fig. 5. The pattern of the geopotential heights at $500 \mathrm{hPa}$ after the rainfall (type I: 1 December 1986).

region. In this situation, the Mediterranean PM system is merged with the Sudan LP system, which in turn force the Azores high pressure (AHP) isobars to move to the lower latitudes.

\section{$500 \mathrm{hPa}$ level}

At middle level of the troposphere, the eastward movement of HP center over the Arabia Peninsula will transport warm humid air from Indian ocean into the region. On the other hand, the deep trough of North Africa will advect higher latitudes cold air behind the stormy system. This condition leads to further intensification of surface frontal systems (Fig. 5). The geopotential height at the center of the low altitude (LA) system over the east Mediterranean is about 540 dam.

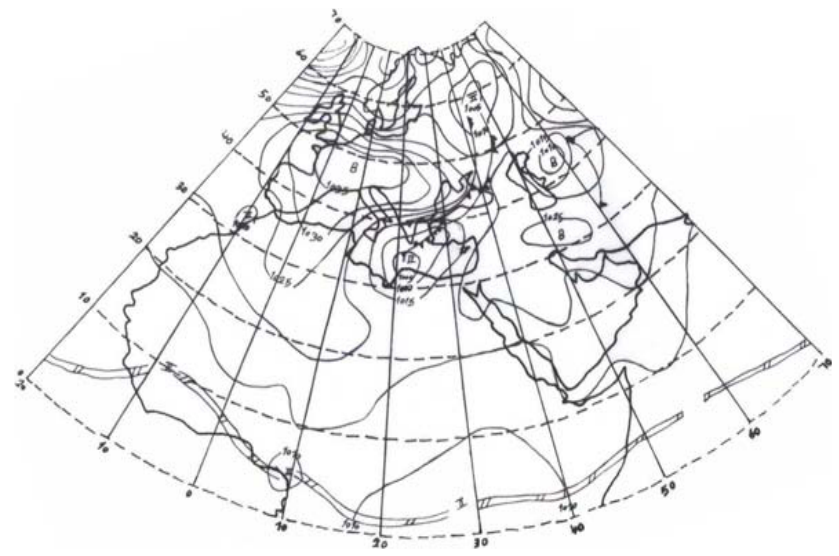

Fig. 6. The pattern of the surface isobars (AAXX) $48 \mathrm{~h}$ before the rainfall (type II: 6 January 1978).

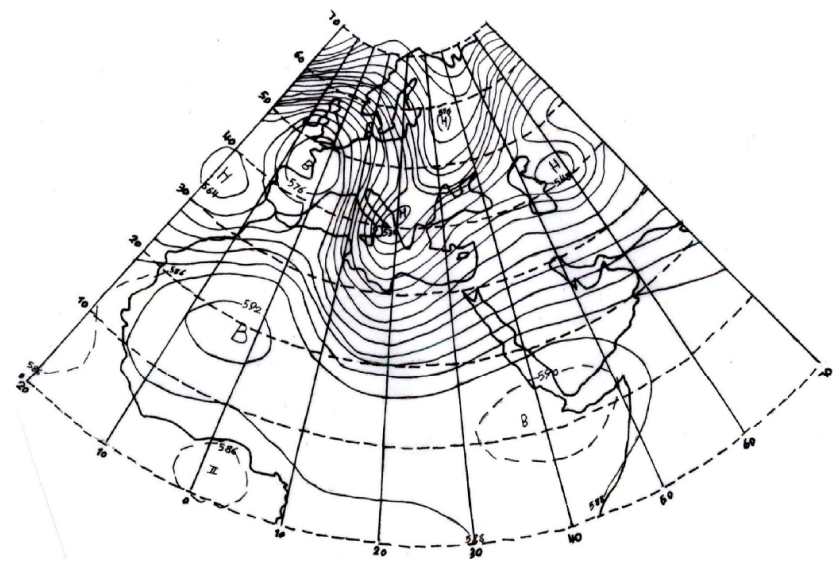

Fig. 7. The pattern of the geopotential heights at $500 \mathrm{hPa}$ before the rainfall (type II: 6 January 1978).

\subsection{Type II}

\subsubsection{Synoptic characteristics before the rainfall}

\section{Surface level}

In type II rain-bearing system, the surface maps at $48 \mathrm{~h}$ prior to rainfall (e.g. Fig. 6) show that the Siberian HP isobars with their southward movement affect most part of Iran. Also, the Azores HP isobars will transport cold air behind the Mediterranean LP system, where is positioned over the Mediterranean Sea. This condition enhances the temperature gradient over this region. Furthermore, merging the Azores HP isobars with Siberian HP isobars above $40^{\circ} \mathrm{N}$, push the Mediterranean and Black sea frontal systems to move to lower latitudes. Before the rains, the central pressure of the anticyclone over Iran is $1025 \mathrm{hPa}$ (Fig. 6). The HP isobars over Saudi Arabia prevents the eastward movement of type II frontal systems. 


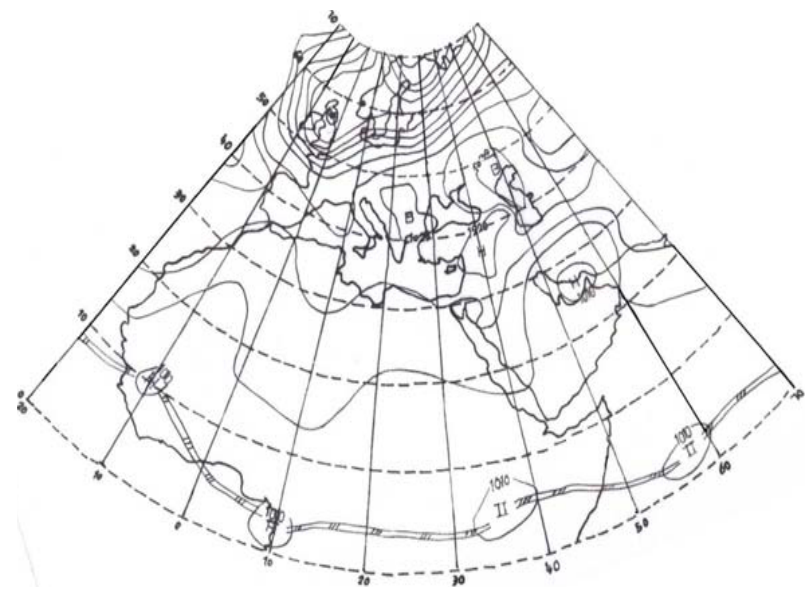

Fig. 8. The pattern of the surface isobars (AAXX) and low pressure center after the heavy rainfalls (type II: 11 January 1978)

\section{$500 \mathrm{hPa}$ level}

The mid-level synoptic pattern at $500 \mathrm{hPa}$ is shown in (Fig. 7). As can be seen, prior to the rains, Azores HP center has created a deep trough over the Mediterranean sea and the north Africa. In this situation, the stream lines of the mentioned trough are meridional, that can transport cold European air to the lower latitudes, just behind the deep African trough. This condition can intensify the flood generating synoptic systems, before arriving to the study region.

\subsubsection{Synoptic characteristics after the rainfall}

\section{Surface level}

When the rain starts falling over the Dalaki basin, the Siberian HP isobars have withdrawn to higher latitudes. As a result, the Sudan LP center with a southwest-northeast movement, approach to Iran causing heavy rainfall over Dalaki basin and the pressure at the core of Sudan LP system falls to $1010 \mathrm{hPa}$ (Fig. 8), causing more instability over fountainheads of Dalaki watershed basin.

\section{$500 \mathrm{hPa}$ level}

Figure 9 shows a sample map of mid-level charts during heavy rainfalls over the region. As it can be seen, the deep Red Sea trough (with a central geopotential height of 552 dam) has penetrated to $13^{\circ} \mathrm{N}$, which allows cold air to descend behind the Sudan dynamic system. On the other hand, the HA center (588 dam) located over Saudi Arabia (Fig. 9) transport warm humid air from Indian ocean to the east of Sudan LP system. This condition will intensify the surface instability over the basin. The significant change of streamlines from zonal mode (before the rains) to meridional flows (during the heavy rains) is of great important.

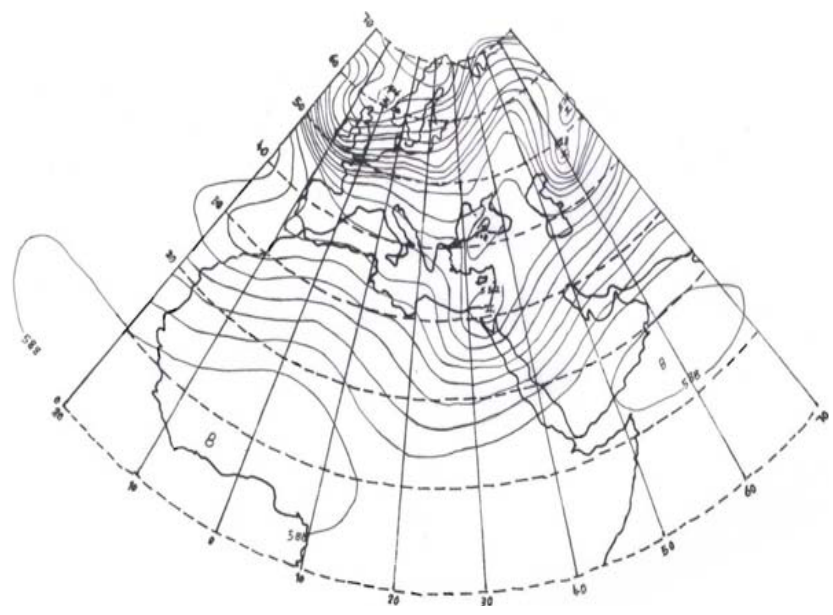

Fig. 9. The pattern of the geopotential heights and the LA center at $500 \mathrm{hPa}$ after the heavy rainfalls (type II: 11 January 1978).

\subsection{Type III}

\subsubsection{Synoptic characteristics before the rainfall}

\section{Surface level}

In this type of flood generating system, the Mediterranean frontal system plays the main role over the region. The Siberian HP isobars extend over Iran and block the eastward movement of the surface frontal system located in the eastern part of the Mediterranean sea (Fig. 10).

\section{$500 \mathrm{hPa}$ level}

Before starting the rains, the upper-level and mid-level charts (e.g. Fig. 11) are characterized by the cold meridional advection at the west Mediterranean sea (caused by Azores HP isobars) and warm advection of African air mass at east of the Mediterranean. This situation can increase the temperature gradient of the frontal system at the surface, before rainfall started. Figure 11 illustrates a sample map of type III flood generating system $48 \mathrm{~h}$ prior to the heavy rainfall. In this case, the heights of the $500 \mathrm{hPa}$ centers over the Mediterranean and south Saudi Arabia is 548 and 588 dam, respectively.

\subsubsection{Synoptic characteristics after the rainfall}

\section{Surface level}

During the rainfall, the Siberian HP isobars move back to the north, allowing low pressure system to approach to the south-west of Iran. In this condition, an intense LP frontal center is formed over Syria, Iraq, and north Saudi Arabia as a result of merging previous Mediterranean LP system and Sudan depression isobars. The central pressure at the core of 


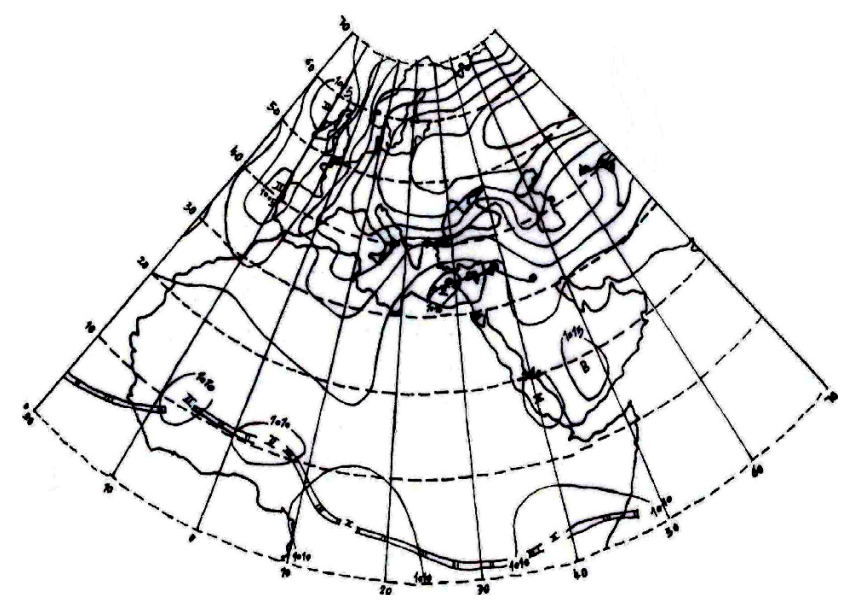

Fig. 10. The pattern of the surface Siberian HP isobars (AAXX) and low pressure center $48 \mathrm{~h}$ before the heavy rainfalls (type III: 15 February 1988).

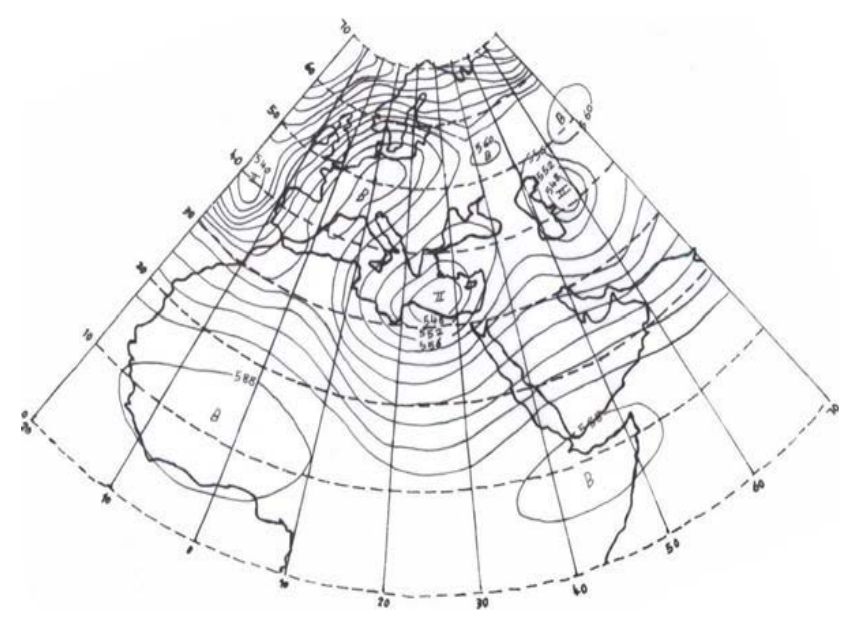

Fig. 11. The pattern of the geopotential heights and the LA center at $500 \mathrm{hPa}$ before the heavy rainfalls (type III: 15 February 1988).

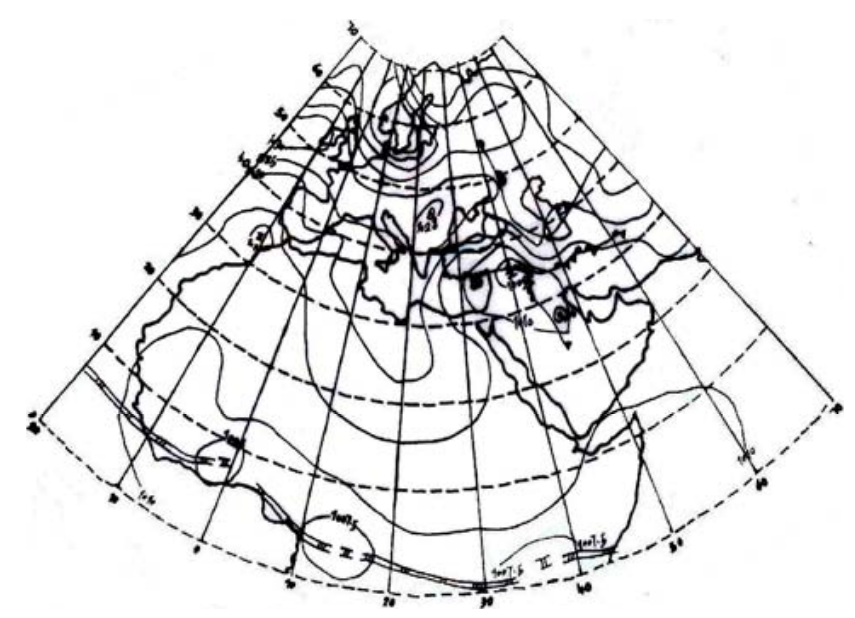

Fig. 12. The pattern of the surface (AAXX) Mediterranean frontal cyclone during the heavy rainfalls (type III: 17 February 1988).

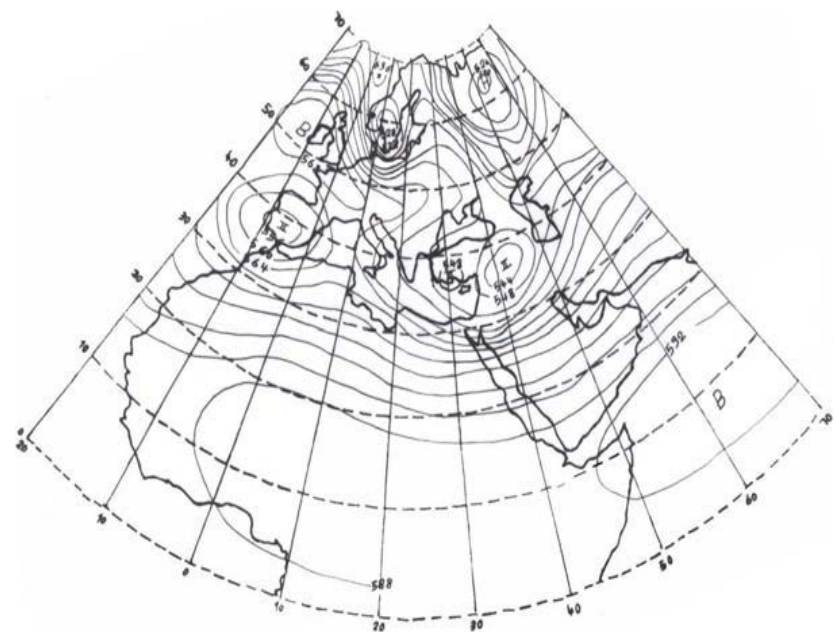

Fig. 13. The pattern of the geopotential heights and the LA center at $500 \mathrm{hPa}$ during the heavy rainfalls (type III: 17 February 1988).

the new merged LP system (i.e. cyclone) is usually less than $1005 \mathrm{hPa}$. Figure 12 shows a sample surface map of type III system during the heavy rainfalls.

\section{0 hPa}

The pattern of mid-level charts during the heavy rains is almost similar to other types of flood generating system, but the position and the geopotential height of mid-level HA center in south Saudi Arabia is slightly different from the other type (Fig. 13).

\subsection{Type IV}

\subsubsection{Synoptic characteristics before the rainfall}

\section{Surface level}

In this type of flood system, the role of Sudan LP is more important compared to the previous case. The surface charts before the rainfall (type IV) show that the SHP isobars, with significant southward shift, cover most part of Iran, Iraq and Saudi Arabia (Fig. 14). At the same time, a closed cyclone and a trough can be observed over the southern Red Sea and Sudan, respectively.

\section{$500 \mathrm{hPa}$}

At mid-level of the atmosphere, a high altitude (HA) system with geopotential height of about 588 dam, covers most parts of Ethiopia and Sudan. In this case, the resulting ridge over the Red Sea and east Mediterranean can cause divergence over Dalaki basin (Fig. 15). 


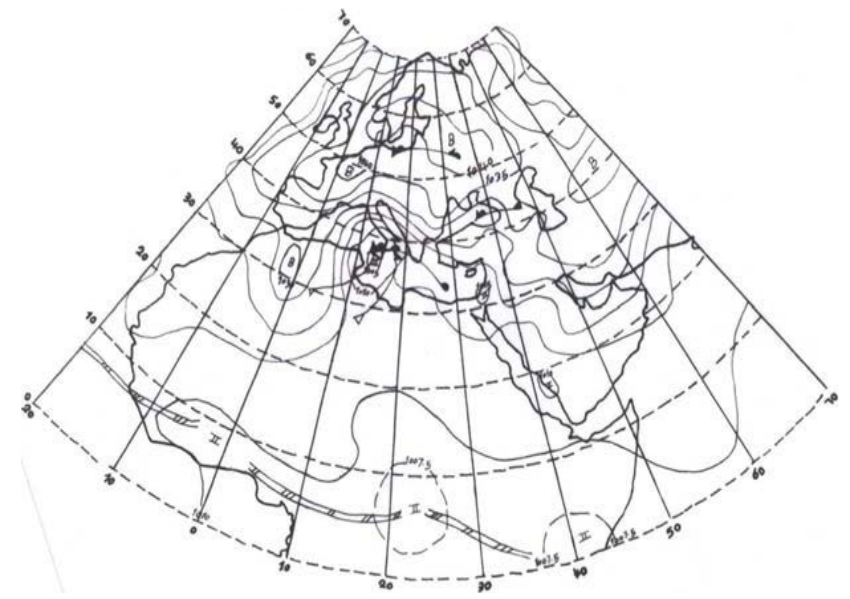

Fig. 14. The pattern of the surface (AAXX) Siberian and Azores isobars $48 \mathrm{~h}$ before the rainfalls (type IV: 30 December 1984).

\subsubsection{Synoptic characteristics after the rainfall}

\section{Surface level}

In this type of flood generating system, the Siberian HP center over Iran moves to the east of the country. In this case, the eastward speed of the Siberian HP center is relatively higher than the speed of the HP center of type I system. Therefore, the southwest of the country and the study region will be prepared for the passage of Sudan LP system (Fig. 16). During the heavy rainfall, the Sudan LP center moves to the higher latitudes and after merging with Mediterranean LP isobars, approach to the Dalaki watershed basin. Under this condition, the Saudi Arabia HP system located at south of this country, will advect warm moist air from the Red Sea and Indian ocean toward the Dalaki region (Fig. 16).

\section{$500 \mathrm{hPa}$}

During the days with heavy rainfalls, several mid-level and low-level waves, which are generated by Sudan and Mediterranean streams, pass over southwest of Iran, causing heavy rains in the region. The advection of cold air by Azores HP isobars will intensify the temperature gradient over the region. A sample of mid-level chart is illustrated in Fig. 17. In type IV system, the gradient of streamlines at $500 \mathrm{hPa}$ is relatively greater than other cases.

\subsection{General conditions of flood generating systems}

Regardless of the type of the synoptic system and the dominant patterns, the position of LP centers, trough lines, and $1010 \mathrm{hPa}$ isobars of all 20 selected cases, at different levels (surface, $700 \mathrm{hPa}$ and $500 \mathrm{hPa}$ ), were also studied. The information were plotted on regional maps from $48 \mathrm{~h}$ prior to the heavy rains in Dalaki region (Figs. 18-23).

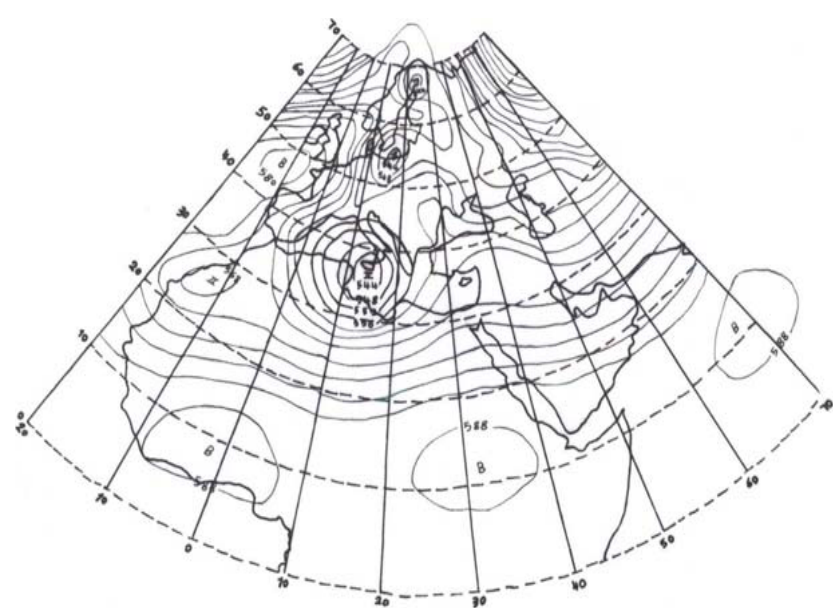

Fig. 15. The pattern of the streamlines and the LA center at $500 \mathrm{hPa}$ $48 \mathrm{~h}$ before the rainfalls (type IV: 30 December 1984).

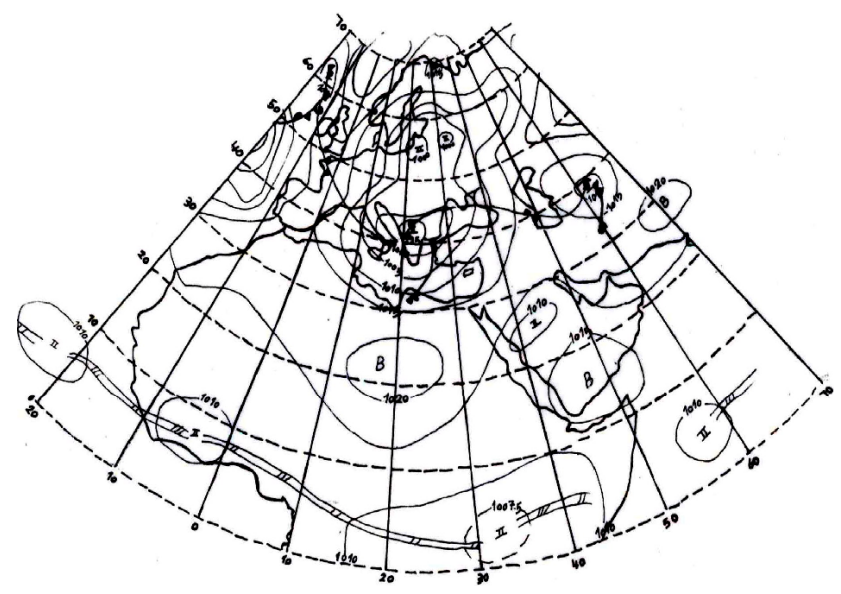

Fig. 16. The pattern of the surface (AAXX) isobars and the Sudan LP center during the heavy rainfalls (type IV: 3 January 1985).

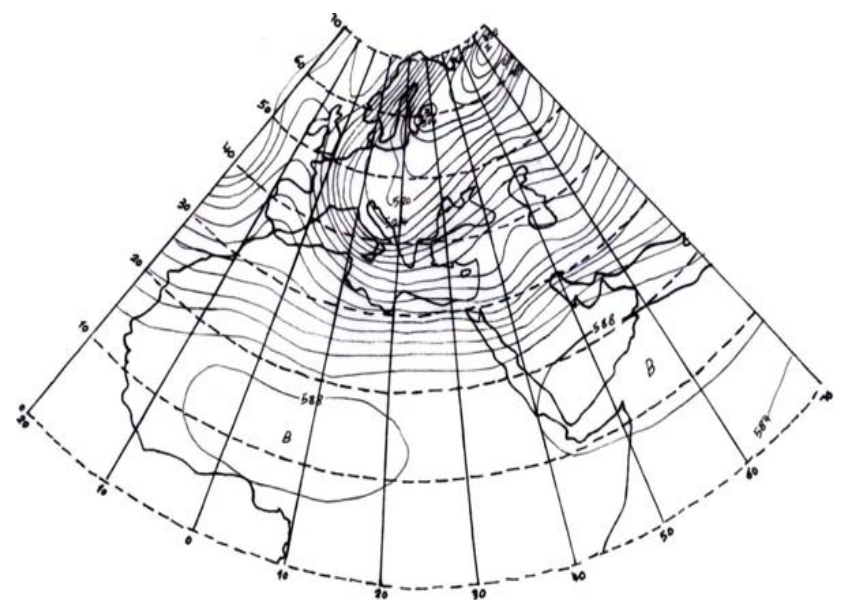

Fig. 17. The pattern of the streamlines and geopotential heights at $500 \mathrm{hPa}$ during the rainfalls (type IV: 3 January 1985). 

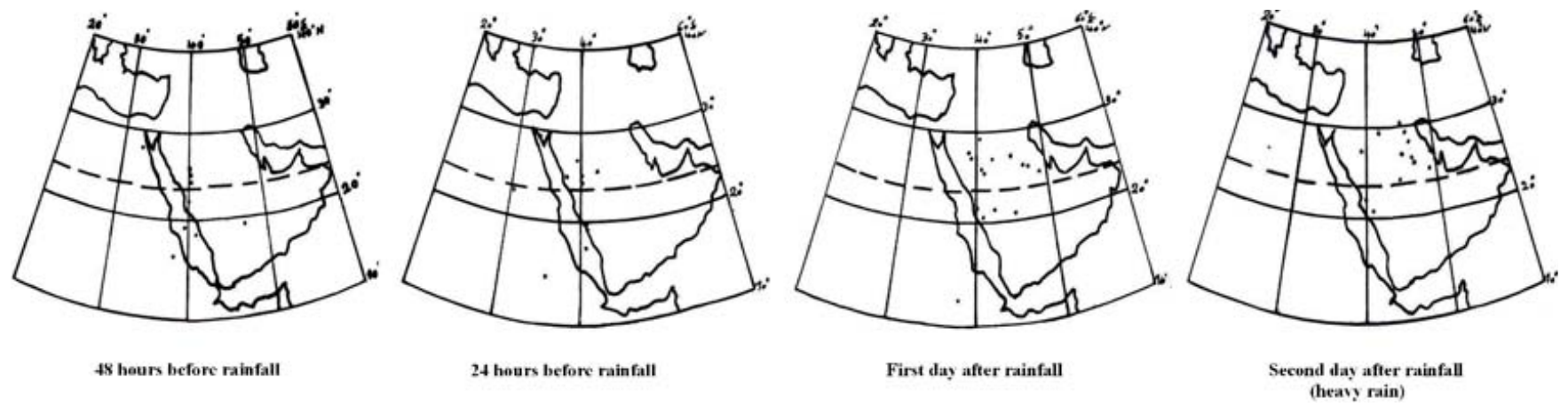

Fig. 18. The location of surface-level LP centers of the 20 selected floods two days before the rainfall (left pictures) and in first day and second day of heavy rainfalls (right pictures).
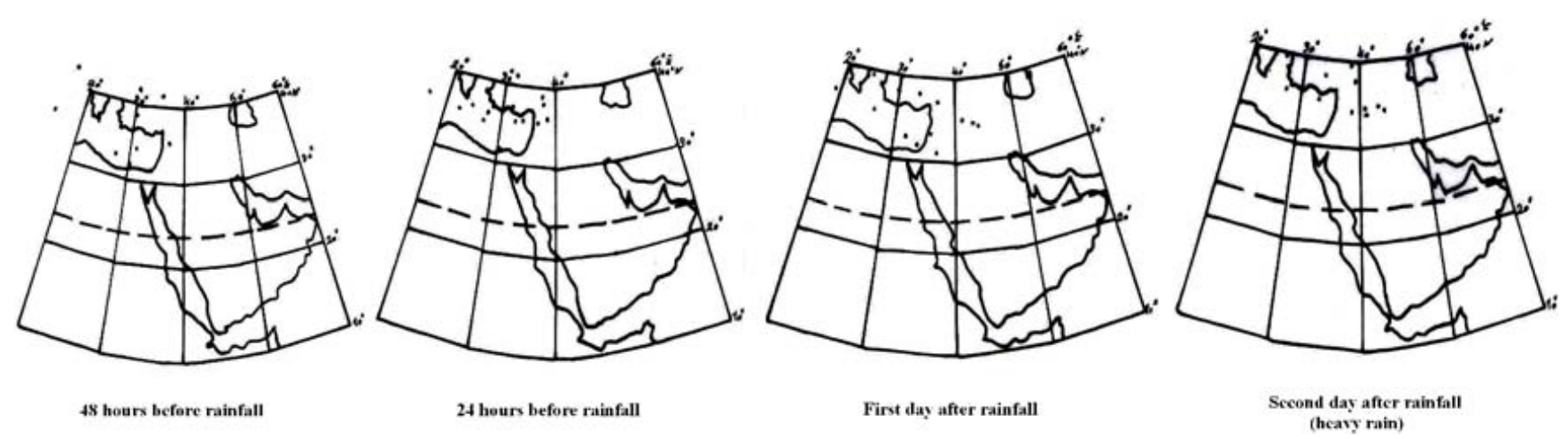

Fig. 19. The location of the $700 \mathrm{hPa}$ LA centers of the 20 selected floods two days before the rainfall (left pictures) and in first day and second day of heavy rainfalls (right pictures).

\subsubsection{Geographical location of LP centers (surface level)}

As it can be seen in Fig. 18, $48 \mathrm{~h}$ before the flood event, the position of LP centers is distributed around the Red Sea. During the first day and second day of heavy rains the centers move eastward, so that in the second day of rain, the LP center are located near Kuwait and east Saudi Arabia.

\subsubsection{The situation of low altitude (LA) centers at $700 \mathrm{hPa}$}

The mean positions of the 20 selected low altitude (LA) centers at $700 \mathrm{hPa}$ are illustrated in Fig. 19. Two days before the rainfall, the LA centers are distributed around $30^{\circ} \mathrm{E}$ (left pictures). On the first day and second day after the heavy rains, the LA centers are transported to $40^{\circ} \mathrm{E}$ (i.e. Syria) with a relatively slow eastward movement (Fig. 19, right pictures).

\subsubsection{The situation of low altitude (LA) centers at $500 \mathrm{hPa}$}

At this level, the mean positions are nearly similar to the $700 \mathrm{hPa}$, so that $48 \mathrm{~h}$ before the rainfall events, they are mostly observed around $25^{\circ} \mathrm{E}$. In $24 \mathrm{~h}$ before observing the rainfall, they are located around $29^{\circ}-36^{\circ} \mathrm{E}$. But on the first day and second day of rainfalls they are observed around $40^{\circ} \mathrm{E}$ (Fig. 20). The comparison of LA centers at $500 \mathrm{hPa}$ and $700 \mathrm{hPa}$ levels with the LP centers at surface shows that $48 \mathrm{~h}$ prior to heavy rainfalls the surface LP centers are distributed over the Red Sea around $20^{\circ} \mathrm{N}$ latitude, (Fig. 18) but the LA centers of $500 \mathrm{hPa}$ and $700 \mathrm{hPa}$ (Figs. 19-20) are seen above $35^{\circ} \mathrm{N}$. This implies that the axis, which pass through the low-level and mid-level centers of flood generating systems are tilted toward the north-west.

\subsubsection{Mean positions of $1015 \mathrm{hPa}$ isobars}

In this study, the mean positions of $1015 \mathrm{hPa}$ isobars that are generated by Sudan depression systems (20 selected cases) were also evaluated. The results indicate that $24-48 \mathrm{~h}$ before the rains, the isobars of $1015 \mathrm{hPa}$ are mainly distributed around west of the Red Sea $\left(25^{\circ} \mathrm{N}\right)$ (Fig. 21, left pictures). By approaching to the floody days, the $1015 \mathrm{hPa}$ isobars move north-east and centered over Kuwait and Dalaki basin (Fig. 21, right pictures). 


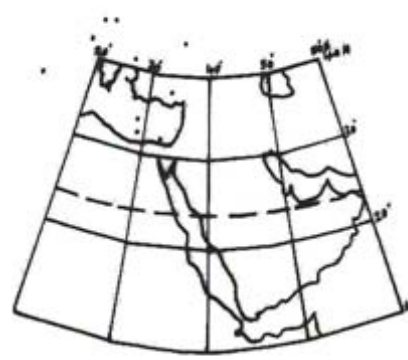

48 hours before rainfall

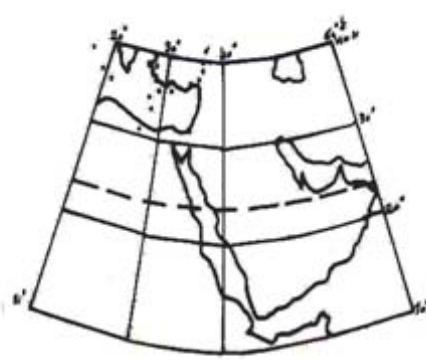

24 heurs before rainfall

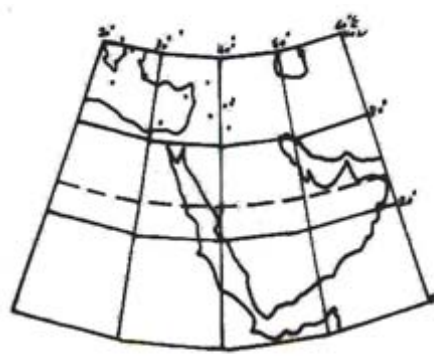

First day after rainfal

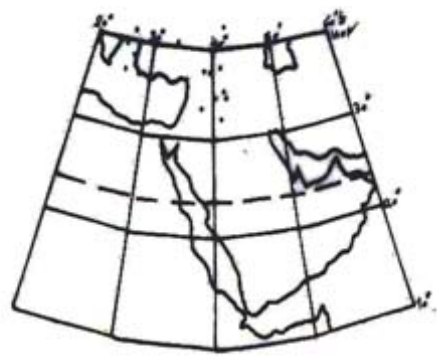

Second day after rainfall (healy rain)

Fig. 20. The location of the $500 \mathrm{hPa}$ LA centers of the 20 selected floods two days before the rainfall (left pictures) and in first day and second day of heavy rainfalls (right pictures).

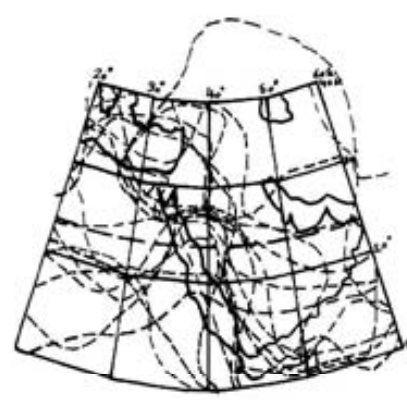

48 hours before rainfall

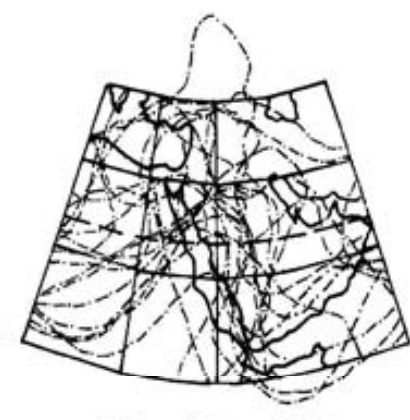

24 hours before rainfall

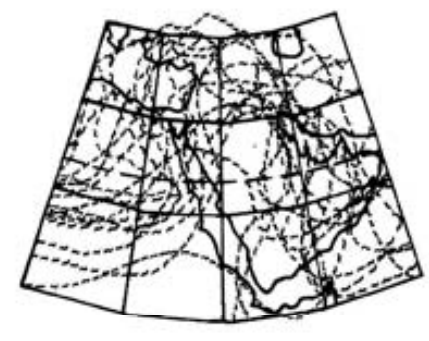

First day after rainfall

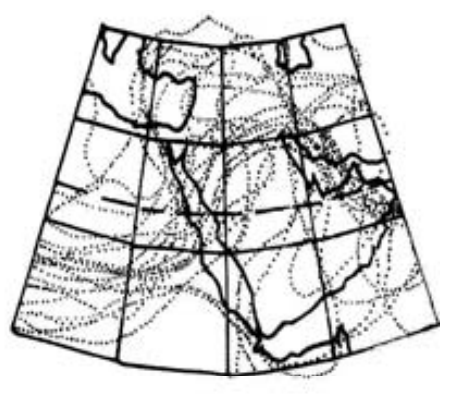

Sceond day after rainfall (heavy rain)

Fig. 21. The mean positions of $1015 \mathrm{hPa}$ isobars of the 20 selected floods, two days before starting the rainfall (left pictures) and in first day and second day after heavy rainfalls (right pictures).

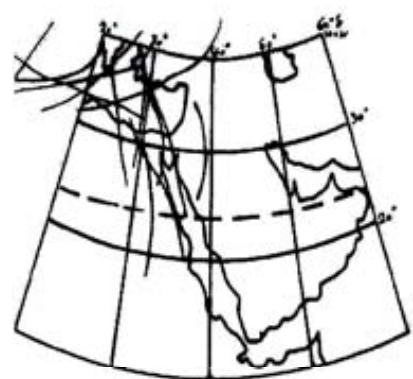

48 hours before rainfal

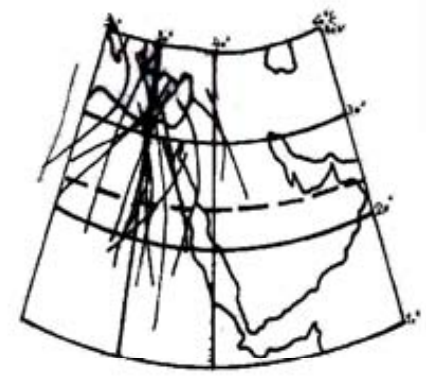

24 hours before rainfall

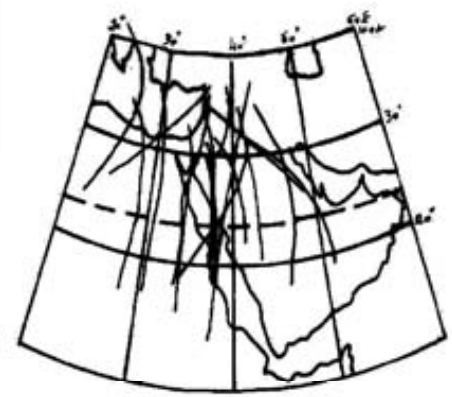

First day after rainfall

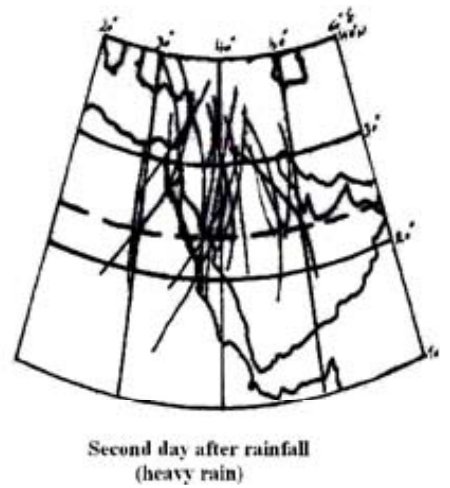

Fig. 22. Trough lines at $700 \mathrm{hPa}$ level, before the rainfall (left pictures) and in first day and second day of heavy rainfalls (right pictures).

\subsubsection{Mean positions of $700 \mathrm{hPa}$ isobars}

Before occurring the rainfall, the trough lines are centered near the eastern Mediterranean and north of the Red Sea $\left(25^{\circ}-30^{\circ} \mathrm{E}\right)$ (Fig. 22, left pictures). By approaching to the rainy days, the trough lines are moved to the southeast $\left(30^{\circ}-\right.$ $\left.40^{\circ} \mathrm{E}\right)$ (Fig. 22, right pictures), so that during the heaviest rainy days, the trough lines at $700 \mathrm{hPa}$ are seen over Saudi
Arabia $\left(43^{\circ} \mathrm{E}\right)$. The eastward movement of the trough lines experiences a mean speed of about 5 degrees per day. The relatively low speed of the trough lines can provide enough time for the forecasters in prediction of torrential rains, before the occurrence of floods over the study region. 

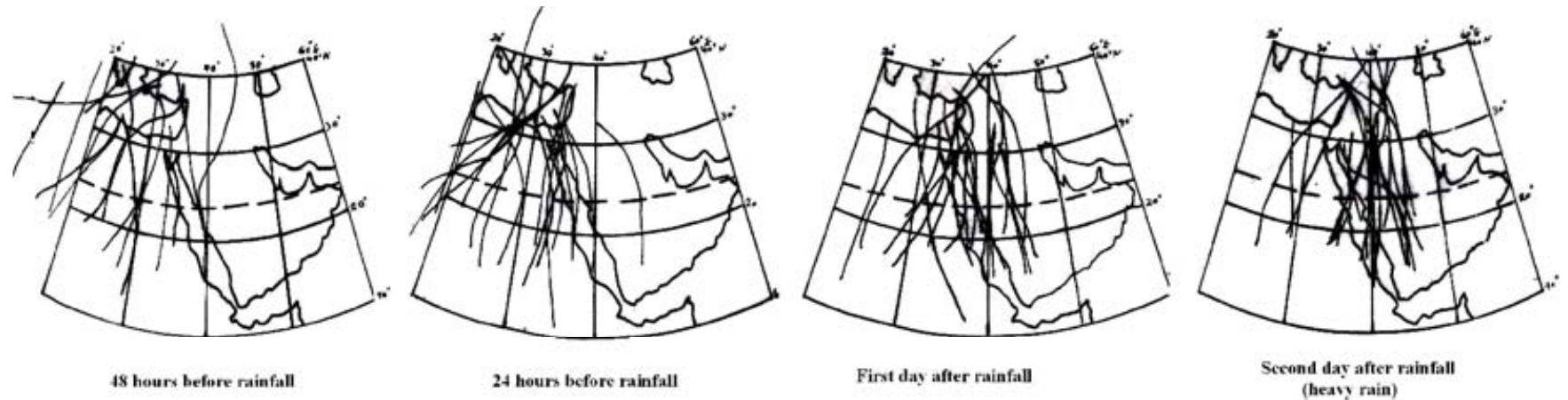

Fig. 23. Trough lines at $500 \mathrm{hPa}$ level, before the rainfall (left pictures) and in first day and second day of heavy rainfalls (right pictures).

\subsubsection{Mean positions of $500 \mathrm{hPa}$ isobars}

The similar characteristics are observed for $500 \mathrm{hPa}$ trough lines. During the heaviest rainy days $(48 \mathrm{~h}$ after starting the rain), the trough lines are centralized over Saudi Arabia $\left(\sim 40^{\circ}\right.$ E) (Fig. 23).

In consistent with the results obtained from the present work, the important role and supportive effect of factors such as the Red Sea trough and mid-level moisture transport from northern Africa and Indian ocean on storm formation have also been addressed by Dayan at al. (2001). The similar synoptic conditions, conductive to cyclogensis and rain-bearing storm which concluded from the present work, are also in agreement with Seluchi (1995) report. The results of this work showed that the main sources of moisture at low-level and mid-level atmosphere are the Mediterranean Sea and Indian ocean. In accordance with Osetinsky and Alpert (2006), the impact of the Red Sea on moisture transport to the eastern Mediterranean was not found to be significant.

\section{Conclusions}

The Mediterranean winter cyclones, Sudan heal lows and Red Sea troughs were known to be the main sources of flood generating systems in south west of Iran. The analysis of the synoptic maps leading to heavy storms, indicated that the flood events over the study region are mainly associated with the special patterns of the surface and mid-level Mediterranean LP systems, Sudan LP, Siberian HP isobars, Azores HP isobars and Red Sea troughs. The coincidence of some of the above synoptic systems $48 \mathrm{~h}$ before the storms was found to be an important factor in increasing the likelihood of flood events over the region.

In summary, the synoptic characteristics of the selected flood generating cases are supported by the following remarkable points:

1. The presence of a deep trough at $500 \mathrm{hPa}$ level east of the Red Sea before starting the rainfalls.
2. Prior to the flood events, the presence of a ridge or a HP center over the Arabia Peninsula and Oman sea feeds warm humid air into the region.

3. The development of Azores HA center at $700 \mathrm{hPa}$ and $500 \mathrm{hPa}$ cause the descent of cold air in the east Mediterranean and North Africa. This condition increased the temperature gradient over Sudan (following by cyclogenesis of Sudan heat low before the heavy rainfall).

4. $48 \mathrm{~h}$ before the torrential rains, the position of Sudan LP center at the surface is likely observed over the Red Sea.

5. During the heaviest rainy days, the Sudan LP centers are moved eastward, to the south of Kuwait.

It was found that the significant change of streamlines from zonal mode (before the rains) to meridional flows (during the heavy rains) is of great importance for identifying the stormy systems before the flood event. Although, the study of other meteorological factors such as upper-level subtropical jet streams on intensifying the surface instability was not in the scope of this research, the evaluation of upper-level jet streams in similar regions worth further investigation. Additional information such as radiosonde data and dew point temperatures of the air masses would increase the accuracy of the flood prediction.

The results of this work can be applied for an operational flood forecasting, provided that the uncertainties of plotting the synoptic maps (i.e. for the meteorological offices that the maps are drawn handy by the operators) are considered. For small and medium watershed basins, the complexity of the orography is also of great importance. It should be reminded that for operational flood forecasting for a watershed basin, in addition to the synoptic information, other data such as the topography, morphology and soil conditions of the study region are required.

Acknowledgements. Special thank must be paid to those who provided the daily weather data and synoptic maps at Iranian Meteorological Office (IRIMO). The Corresponding author is grateful to the Bu-Ali Sina University (BASU) for their support. 
Edited by: N. R. Dalezios

Reviewed by: two anonymous referees

\section{References}

Alexander, M., Rashid, J., Shamuddin, S. D., and Alam, M. S.: Flood control, drainage and irrigation projects in Bangladesh and their impact on soils, Land Degrad. Dev., 9(3), 233-246, 1998.

Bagheri, S.: Investigation of flood-generating synoptic systems in North Iran, M.Sc. dissertation, Institute of Geophysics, University of Tehran, Iran, 1993 (in Persian).

Březková, L., Š́ak, M., Soukalová, E., and Starý, M.: Predictability of flood events in view of current meteorology and hydrology in the conditions of the Czech Republic, Soil and Water Research, 2(4), 156-168, 2007.

Calena, G. and Barbet, D.: Influence of vegetation cover on flood hydrology in experimental basins in Mt. Lozere, Hydrologie Continentale, 7(1), 33-49, 1992.

Chai, X., Hong, X., Shun, H., Chai, Z., Hong, L., and Shun, G.: Relationship between flood and forest, vegetation in Zheyiarg Provinces in 1994, Acta Agriculture, 7(2), 97-100, 1995.

Cozari, F. and Fontan, G. D.: Effect of land use change on flood hazard, Proceedings of Eighth annual symposium on GIS in Natural Resources Management, 453-461, 1994.

Dayan, U., Ziv, B., Margalit, A., Morin, E., and Sharon, D.: A severe autumn storm over the Middle-East: Synoptic and mesoscale condition analysis, Theor. Appl. Climatol., 69, 103122, 2001.

Dinpashoh, Y., Fakheri-Fard, A., and Moghaddam, M.: Selection of variables for the purpose of regionalization of Iran's precipitation climate using multivariate methods, J. Hydrol., 297(1-4), 109123, 2004.

Hall, J. W., Sayers, P. B., and Dawson, J. S.: National-scale assessment of current and future flood risk in England and Wales, Nat. Hazards, 36, 147-164, 2005.

Jamab: Integrated Report of Water Research in Iran: ShapourDalaki river basin. Iranian Ministry of Energy, Jamab Engineering Consulting Group, 1, 174 pp., 1990 (in Persian).
Kahana, R., Ziv, B., Dayan, U., and Enzel, Y.: Atmospheric predictors for major floods in the Negev desert, Israel, Int. J. Climatol., 24, 1137-1147, 2004.

Konrad, C. E.: Synoptic scale features associated with warm season heavy Rainfall over the interior South Eastern United Stated, Weather Forecast., 12(3), 557-571, 1997.

Morin, E., Harats, N., Jacoby, Y., Arbel, S., Getker, M., Arazi, A., Grodek, T., Ziv, B., and Dayan, U.: Studying the extremes: hydrometeorological investigation of a flood-causing rainstorm over Israel, Adv. Geosci., 12, 107-114, doi:10.5194/adgeo-12107-2007, 2007.

Osetinsky, I. and Alpert, P.: Calendaricities and multimodality in the Eastern Mediterranean cyclonic activity, Nat. Hazards Earth Syst. Sci., 6, 587-596, doi:10.5194/nhess-6-587-2006, 2006.

Sabziparvar, A. A.: Synoptic study of torrential rainfalls in SouthWest of Iran, M.Sc. dissertation, Institute of Geophysics, University of Tehran, Iran, 1991 (in Persian).

Sabziparvar, A. A. and Ghafouri, M.: National study on evidences and impacts of climate change with focus on water resources management (I.R. of Iran), Report prepared for the Regional FAO Office, Italy, Rome, 154 pp., 2008.

Sabziparvar, A. A.: A Simple formula for estimation global solar radiation in central arid deserts of Iran, Renew. Energ., 33(5), 1002-1010, 2008.

Seluchi, M. E.: Diagnosis and prognosis of synoptic conditions conductive to cyclogenesis over eastern South America, Geofisica Internacional, 34(2), 171-186, 1995.

Taramasso, A. C., Gabellani, S., and Parodi, A.: An operational flash-flood forecasting chain applied to the test cases of the EU project HYDROPTIMET, Nat. Hazards Earth Syst. Sci., 5, 703710, doi:10.5194/nhess-5-703-2005, 2005.

Turner, J., Colwell, S. R., and Harangozo, S.: Variability of precipitation over the coastal western Antarctic Peninsula from synoptic observation, J. Geophys. Res.-Atmos., 102(D12), 13999-14007, doi:10.1029/96JD03359.

Ziv, B., Dayan, U., and Sharon, D.: A mid-winter, tropical extreme flood-producing storm in southern Israel: synoptic scale analysis, Meteorol. Atmos. Phys., 88(1-2), 53-63, 2005. 